\title{
Elutriated lymphocytes for manufacturing chimeric antigen receptor $T$ cells
}

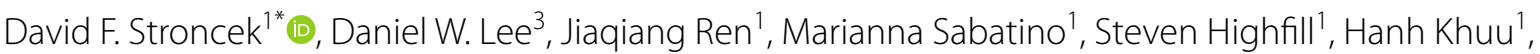 \\ Nirali N. Shah², Rosandra N. Kaplan², Terry J. Fry² and Crystal L. Mackall4
}

\begin{abstract}
Background: Clinical trials of Chimeric Antigen Receptor (CAR) T cells manufactured from autologous peripheral blood mononuclear cell (PBMC) concentrates for the treatment of hematologic malignancies have been promising, but CART cell yields have been variable. This variability is due in part to the contamination of the PBMC concentrates with monocytes and granulocytes.

Methods: Counter-flow elutriation allows for the closed system separation of lymphocytes from monocytes and granulocytes. We investigated the use of PBMC concentrates enriched for lymphocytes using elutriation for manufacturing 8 CD19- and 5 GD2-CART cell products.

Results: When compared to PBMC concentrates, lymphocyte-enriched elutriation fractions contained greater proportions of CD3+ and CD56+ cells and reduced proportions of CD14+ and CD15+ cells. All 13 CART cell products manufactured using the elutriated lymphocytes yielded sufficient quantities of transduced CART cells to meet clinical dose criteria. The GD2-CART cell products contained significantly more T cells and transduced T cells than the CD19CART cell products. A comparison of the yields of CART cells produced from elutriated lymphocytes with the yields of CART cells previous produced from cells isolated from PBMC concentrates by anti-CD3/CD28 bead selection or by anti-CD3/CD28 bead selection plus plastic adherence found that greater quantities of GD2-CART cells were produced from elutriated lymphocytes, but not CD19-CART cells.
\end{abstract}

Conclusions: Enrichment of PBMC concentrates for lymphocytes using elutriation increased the quantity of GD2CART cells produced. These results provide further evidence that CART cell expansion is inhibited by monocytes and granulocytes.

Keywords: Chimeric antigen receptor T cells, Cancer immunotherapy, Cellular therapy, $T$ cells, Elutriation, Myeloid derived suppressor cells, Peripheral blood mononuclear cells

\section{Background}

Early phase clinic trials of $\mathrm{T}$ cells genetically engineered to express chimeric antigen receptors (CAR) have been encouraging. CD19-CAR T cells have been used successfully in a number of clinical trials to treat non-Hodgkin lymphoma and acute lymphocytic leukemia (ALL)

\footnotetext{
*Correspondence: dstroncek@cc.nih.gov

${ }^{1}$ Cell Processing Section, Department of Transfusion Medicine, $\mathrm{NIH}$ Clinical Center, NIH, 10 Center Drive-MSC-1184, Building 10, Room 3C720, Bethesda, MD 20892-1184, USA

Full list of author information is available at the end of the article
}

[1-8]. Preliminary studies of B cell maturation antigen (BCMA)-CAR $\mathrm{T}$ cells to treat multiple myeloma have also been promising [9].

Most CAR T cell manufacturing protocols initate cell production with autologous $\mathrm{T}$ cells collected by apheresis using a blood cell separator which separates lymphocytes from plasma, platelets, red blood cells (RBCs) and granulocytes. However, the lymphocyte-rich peripheral blood mononuclear cell (PBMC) concentrates collected by apheresis are also enriched for monocytes and contain variable quantities of RBCs, platelets and granulocytes. 
The quantities of these contaminating cells are dependent on the type of blood cell separator and how the blood cell separator is operated. The composition of the PBMC concentrates are also dependent on the type of tumor (solid vs. liquid), and the patient's blood counts at the time of collection [10]. While the quantities of these contaminating RBCs, platelets and granulocytes cells can be minimized with highly trained users of the cell separator instrument, they cannot be completely eliminated. Consequently, prior to beginning the CAR T cell manufacturing process the PBMC concentrates are generally enriched for lymphocytes or CD3+ cells in the cell processing laboratory.

Our center initially manufactured CD19- and GD2CAR $\mathrm{T}$ cells using autologous PBMC concentrates enriched for $\mathrm{T}$ cells by magnetic selection with the anti-CD3/CD28 beads. These same anti-CD3/CD28 beads were also used to stimulate $\mathrm{T}$ cell expansion. While the method was, in general, effective, we found that the quantities of GD2-CAR T cells produced were less than the quantities of CD19-CAR T cells produced [11]. In addition, CAR T cells from some patients failed to expand to sufficient levels to meet patient treatment dose criteria. Upon further investigation, we discovered that the presence of large quantities of monocytes or granulocytes in some PBMC concentrates was associated with poor in vitro expansion of CAR T cells [11]. We modified the $\mathrm{T}$ cell enrichment method to include a plastic adherence step to deplete PBMC concentrates of monocytes prior to the anti-CD3/CD28 bead enrichment step. This modified $\mathrm{T}$ cell enrichment process improved $\mathrm{T}$ cell expansion, but it was not completely effective at removing contaminating monocytes and granulocytes and did not completely eliminate manufacturing failures [11].

We hypothesized that more rigorous enrichment of the starting material for lymphocytes would improve the yield of transduced $\mathrm{T}$ cells and reduce the incidence of manufacturing failures. A semi-automated counter-flow elutriation instrument is available for enriching PBMC concentrates for monocytes and lymphocytes which makes use of a sterile single use disposable kit [12].

We modified our CAR $T$ cell manufacturing process to include elutriation for the enrichment of PMBC concentrates for lymphocytes rather than anti-CD3/CD28 bead selection or anti-CD3/CD28 bead selection plus plasitic adherence. We report the results of manufacturing CD19- and GD2-CAR T cells using lymphocytes collected by apheresis and enriched by elutriation as starting material. We also compared CD19- and GD2CAR $T$ cells manufactured from elutriated lymphocytes with those that we previously manufactured from PBMC concentrates that were enriched for lymphocytes with
anti-CD3/CD28 bead selection or bead selection plus plastic adherence [11].

\section{Methods \\ Study participants}

Patients in this study were enrolled in an open-label phase 1 dose-escalation study of CD19-CAR T cells in children and young adults with ALL or non-Hodgkin lymphoma, NCT01593696, or an open-label phase 1 dose-escalation study of GD2-CAR T cell in children and young adults with GD2 expressing osteosarcoma or neuroblastoma, NCT02107963. Clinical results of the first 21 of the patients receiving CD19-CAR T cell therapy have previously been reported [1]. The results of CD19-CAR $\mathrm{T}$ cell manufacturing from the first 43 patients and GD2CAR T cells from the first 11 patients have previous been reported [11]. This study reports the results of manufacturing CD19-CAR T cells from 8 additional patients and GD2-CAR T cells from 5 additional patients. Among the 8 patients treated with CD19-CAR T cells 7 had ALL and one had diffuse large B cell lymphoma (DLBCL). All 5 patients treated with GD2-CAR T cells all had osteosarcoma. All 8 patients receiving CD19-CAR T cells were given a dose of $1 \times 10^{6}$ cells $/ \mathrm{kg}$ and 2 patients receiving GD2-CAR T cells were given a dose of $3 \times 10^{6}$ CAR $\mathrm{T}$ cells/kg and 3 patients were given a dose of $1 \times 10^{7}$ CAR T cells $/ \mathrm{kg}$. All subjects were enrolled in protocols approved by the National Cancer Institute (NCI) Institutional Review Board and inform consent was obtained.

We also compared the results of manufacturing CD19and GD2-CAR T cells in this study with the previously reported results of manufacturing CD19- and GD2-CAR $\mathrm{T}$ cells using PBMC concentrates enriched for $\mathrm{T}$ cells by selection with anti-CD3/CD28 beads with and without plastic adherence [11].

\section{Manufacturing CART cells}

Peripheral blood mononuclear cells concentrates were collected using a blood cell separator (Cobe Spectra, Terumo BCT, Lakewood, CO, USA) and 10-15 L of blood was processed. CD19-CAR $\mathrm{T}$ cells were manufactured from PBMC concentrates using a modification of the method we previously described $[11,13]$. When PBMCs were enriched for lymphocytes by anti-CD3/CD28 bead selection, on day 0 , a fresh or cryopreserved PBMC concentrate containing $600 \times 10^{6} \mathrm{CD} 3+$ cells were enriched for CD3+ cells using anti-CD3/CD28 antibodies bound to paramagnetic beads (Dynabeads ClinExVivo CD3/CD28, Invitrogen, Camarillo, CA) at a ratio of 3:1 (beads:cells). The cells and beads were co-incubated for $2 \mathrm{~h}$ at room temperature and CD3+ cell enrichment was performed using Dynal ClinExVIVO MPC magnet (Invitrogen, Camarillo, CA). A total of $100 \times 10^{6}$ cells in the 
CD3 + fraction were resuspended at a concentration of $1 \times 10^{6}$ cells $/ \mathrm{mL}$ in PermaLife bags (OriGen Biomedical, Austin, TX) at $37{ }^{\circ} \mathrm{C}$ in $5 \% \mathrm{CO}_{2}$ in AIM V medium (Gibco, Grand Island, NY), supplemented with 5\% heatinactivated human AB Serum (Valley Biomedical, Winchester, VA), 1\% Gluta-Max (Gibco, Grand Island, NY), $40 \mathrm{IU} / \mathrm{mL}$ IL-2 (Novartis Vaccines and Diagnostics, Inc. Emeryville, CA).

For manufacturing CD19-CAR $\mathrm{T}$ cells, the lymphocyte enriched cells were transduced twice with clinical grade MSGV-FMC63-28Z recombinant retroviral vector supernatant, once on day 2 and once on day 3, in retronectin-coated bags. The cells were maintained in culture for 7-9 days. The cell concentration was maintained at $0.4 \times 10^{6}$ cells $/ \mathrm{mL}$ by adding fresh media every other day. On the day of harvest the anti-CD3/CD28 paramagnetic beads were removed using the Dynal ClinExVIVO MPC magnet (Invitrogen, Camarillo, CA), washed, concentrated and quality control assessment was performed.

For manufacturing GD2-CAR T cells, the same lymphocyte enrichment processes was used and a similar process was used to transduce and expand the cells. Cells were transduced once on day 2 with anti-GD2.28.z.OX40. ICD9 retroviral vector supernatant and were harvested after 10 or 11 days in culture.

When PBMC concentrates were enriched for lymphocytes by anti-CD3/CD28 bead selection plus plastic adherence the PBMC concentrates were incubated with anti-CD3/CD28 beads for $2 \mathrm{~h}$ in $\mathrm{T}$ flasks rather than in bags. At the end of the $2 \mathrm{~h}$ incubation period the nonadherent cells were collected and the cells were processed as described above.

When the PBMC concentrates were enriched for lymphocytes by elutriation they were subject to elutriation using a semi-automatic counter-flow elutriation instrument (Elutra Cell Separation System, version 1.1, Terumo $\mathrm{BCT}$ ) using a user defined profile which collects cells in 5 fractions. The chamber rotation speed was maintained at 2400 RPMs for fractions 1 through 4 and the media flow rate was maintained at $60 \mathrm{~mL} / \mathrm{min}$ for fraction 1 , $120 \mathrm{~mL} / \mathrm{min}$ for fraction $2,122 \mathrm{~mL} / \mathrm{min}$ for fraction 3 and $124 \mathrm{~mL} / \mathrm{min}$ for fraction 4 . Fraction 5 was the cells remaining in the chamber and they were collected with the rotor turned off. Lymphocytes were found in fractions 1 and 2 and monocytes and granulocytes were in fraction 5. Fraction 1 and 2 also were enriched with platelets and RBCs [12].

The lymphocyte fraction was depleted of RBCs by lysis. The cells were pelleted by centrifugation, incubated for 7-10 min with ACK Lysing Buffer (Lonza, Walkersville, $\mathrm{MD}$ ) and then washed and resuspended in $0.9 \%$ saline (B.Braun Medical Inc., Irvine, CA) with 0.3\% trisodium citrate (TriCitrasol anticoagulant sodium citrate concentrate $46.7 \%$, Citra Labs, Braintree, MA).

\section{Cell counts and flow cytometry}

Blood counts were measured using automated hematology analyzer (Cell-Dyn 3700). Flow cytometry was performed with a FACSCanto II (BeckinDickinson) using CD3, CD4, CD8, CD14, CD15, CD19, CD45 and CD56 antibodies (BD Biosciences, San Jose, CA). The expression of CD19-CAR and GD2-CAR was assessed by flow cytometry with anti-idiotype antibodies.

\section{Statistically analysis}

The values shown are mean \pm 1 standard deviation unless otherwise indicated. Groups were compared using $t$-tests (Microsoft Excel, Microsoft Inc., Redmond, WA).

\section{Results}

\section{Composition of the PBMC concentrates and elutriated lymphocytes}

We manufactured 8 CD19 CAR T cell products and 5 GD2-CAR T cell products using autologous PBMC concentrates collected by apheresis and enriched for lymphocytes by elutriation. The PBMC concentrates, as expected, contained significant quantities of monocytes and neutrophils in addition to the desired lymphocytes (Table 1).

To assess the effectiveness of elutriation for lymphocyte enrichment the PBMC concentrates and the elutriated lymphocyte fractions were analyzed by flow cytometry with anti-CD3, anti-CD19, anti-CD14, anti-CD15 and anti-CD56 for T cells, B cells, monocytes, neutrophils and NK cells, respectively (Table 2). Among all of the procedures analyzed the elutriated lymphocytes were enriched for CD3+ cells and CD56+ cells and had reduced levels of CD14+ and CD15+ cells. There was no difference in the proportion of CD19+ cells in the PBMC concentrates and lymphocytes fraction. The elutriated lymphocytes from patients enrolled in both the CD19- and GD2CAR $\mathrm{T}$ cell protocols contained a greater proportion

Table 1 Proportion of leukocytes in autologous PBMC concentrates collected for CD19- and GD2-CAR T cell manufacturing

\begin{tabular}{lcccc}
\hline Cell type & \multicolumn{3}{l}{ CAR cell type } \\
\cline { 2 - 5 } & $\mathbf{n}$ & $\mathbf{C D 1 9}(\mathbf{n}=\mathbf{8})$ & $\mathbf{G D 2}(\mathbf{n}=\mathbf{5})$ & All $(\mathbf{n}=\mathbf{1 3})$ \\
\hline Neutrophils & $(\%)$ & $11.0 \pm 18.2$ & $5.2 \pm 3.6(1-10)$ & $\begin{array}{c}8.8 \pm 14.4 \\
(1-58)\end{array}$ \\
Lymphocytes & $(\%)$ & $59.1 \pm 24.1$ & $65.8 \pm 6.8$ & $61.7 \pm 24.7$ \\
& & $(7-84)$ & $(58-78)$ & $(7-89)$ \\
Monocytes & $(\%)$ & $27.1 \pm 12.3$ & $26.4 \pm 6.2$ & $26.8 \pm 12.2$ \\
& & $(8-45)$ & $(19-38)$ & $(8-45)$ \\
\hline
\end{tabular}

a Values represent the mean \pm SD and range 
Table 2 Comparison of the composition of PBMC concentrates and the elutriated lymphocyte fraction used to manufacture CD19- and GD2-CAR T cells

\begin{tabular}{|c|c|c|c|c|c|c|c|c|c|}
\hline \multirow[t]{3}{*}{ Cell type } & \multicolumn{9}{|c|}{ CAR T cell type } \\
\hline & \multicolumn{3}{|c|}{ CD19 } & \multicolumn{3}{|c|}{ GD2 } & \multicolumn{3}{|l|}{ All } \\
\hline & $n$ & PBMC & Elutriated lymphs & $n$ & PBMC & Elutriated Lymphs & $n$ & PBMC & Elutriated lymphs \\
\hline $\mathrm{CD} 3+$ & 8 & $49.0 \pm 23.1$ & $62.1 \pm 24.4^{\mathrm{a}}$ & 5 & $42.2 \pm 17.0$ & $58.0 \pm 23.0^{a}$ & 13 & $49.3 \pm 22.5$ & $64.6 \pm 25.5^{a}$ \\
\hline CD14+ & 8 & $17.2 \pm 11.4$ & $3.5 \pm 1.7^{\mathrm{a}}$ & 4 & $20.9 \pm 9.7$ & $3.9 \pm 3.2^{\mathrm{a}}$ & 12 & $19.9 \pm 13.7$ & $3.6 \pm 4.8^{\mathrm{a}}$ \\
\hline CD15+ & 8 & $8.2 \pm 15.2$ & $4.1 \pm 10.6$ & 4 & $3.9 \pm 2.8$ & $0.8 \pm 1.4$ & 12 & $6.9 \pm 12.0$ & $2.9 \pm 8.2^{\mathrm{a}}$ \\
\hline CD19+ & 8 & $13.8 \pm 16.9$ & $13.4 \pm 16.4$ & 2 & $10.4 \pm 6.7$ & $14.5 \pm 9.2$ & 10 & $14.0 \pm 14.7$ & $11.9 \pm 8.6$ \\
\hline CD56+ & 8 & $7.4 \pm 4.9$ & $12.6 \pm 8.5^{\mathrm{a}}$ & 2 & $4.8 \pm 2.8$ & $6.8 \pm 3.8$ & 10 & $7.2 \pm 5.0$ & $11.9 \pm 8.6^{\mathrm{a}}$ \\
\hline
\end{tabular}

${ }^{a} \mathrm{p}<0.05$ Paired T-tests of pre- and post-elutriation samples

Values represent the mean \pm SD

of CD3+ and less CD14+ cells than the PBMC concentrates. The lymphocyte fraction from CD19-CAR T patients was also enriched for CD56+ cells.

Manufacturing CD19- and GD2-CAR T cells using elutriated lymphocytes

All 13 CAR $\mathrm{T}$ cell manufacturing procedures yielded sufficient quantities of $\mathrm{T}$ cells to meet the dose criteria $\left(1 \times 10^{6} / \mathrm{kg}\right.$ for CD19-CAR T cells and $3 \times 10^{6}$ or $1 \times 10^{7}$ cells $/ \mathrm{kg}$ for GD2-CAR T cells). The 13 CAR T cell products contained $2166 \pm 1113 \times 10^{6} \mathrm{CD} 3+$ cells and $1064 \pm 877 \times 10^{6}$ transduced CD3+ T cells. The GD2CAR $\mathrm{T}$ cell final products contained more total nucleated cells (TNC), CD3+ cells and transduced CD3+ cells than the CD19-CAR T cell final products (Table 3). There was no difference among CD19- and GD2-CAR $\mathrm{T}$ cell final products in the proportion of $\mathrm{CD} 3+$ cells or transduced CD3+ cells (Table 3 ). The proportion of CD3+ cells that expressed CD4 or CD8 was also similar among CD19- and GD2-CAR T cell final products (Table 3). The proportion of CD19+ cells was also measured in the CD19-CAR T cell final products and very few were detected, $0.1 \pm 0.1 \%$, range $=0.0-0.2 \%$.

\section{Comparison of CAR T cells manufactured using} lymphocytes enriched by anti-CD3/CD28 bead selection with and without plastic adherence and elutriation

We compared the yields of CAR T cells produced from PBMC concentrates enriched for lymphocytes by elutriation in this study and those produced from PBMC concentrates enriched for lymphocytes by anti-CD3/CD28 beads with and without plasitic adherence in a previous study [11]. For GD2-CAR T cell products, greater quantities of $\mathrm{T}$ cells were produced from elutriated lymphocytes $\left(4119 \pm 934 \times 10^{6}\right)$ than from anti-CD3/ CD8 bead enriched $\left(183 \pm 106 \times 10^{6} ; p=6.73 \times 10^{-6}\right)$ and anti-CD3/CD28 bead plus adherence enriched cells $\left(1404 \pm 1136 \times 10^{6} ; p=6.14 \times 10^{-3}\right)$ (Fig. 1a) and greater quantities of $\mathrm{CD} 3+$ transduced GD2CAR $\mathrm{T}$ cells were produced from elutriated lymphocytes $\left(1940 \pm 775 \times 10^{6}\right)$ than from anti-CD3/CD28 bead enriched $\left(147 \pm 102 \times 10^{6} ; p=6.68 \times 10^{-4}\right)$ and

Table 3 Quantity of total nucleated cells, CD3+ cells and transduced CD3+ cells in the final CAR T cell products and CD4+ and CD8+ cell content of the final products

\begin{tabular}{|c|c|c|c|c|c|c|}
\hline \multirow[t]{3}{*}{ Cell type } & \multicolumn{6}{|c|}{ CAR T cell type } \\
\hline & \multicolumn{2}{|l|}{$\mathrm{CD} 19(\mathrm{n}=8)$} & \multicolumn{2}{|l|}{ GD2 $(n=5)$} & \multicolumn{2}{|l|}{ All $(n=13)$} \\
\hline & Mean \pm SD & Range & Mean \pm SD & Range & Mean \pm SD & Range \\
\hline TNC $\left(\times 10^{6}\right)$ & $981 \pm 235$ & $668-1440$ & $4384 \pm 1194^{\mathrm{a}}$ & $2250-6610$ & $2289 \pm 1865$ & $668-6160$ \\
\hline CD3 + cells $\left(\times 10^{6}\right)$ & $946 \pm 273$ & $500-1434$ & $4119 \pm 934^{\mathrm{a}}$ & 2499-5119 & $2166 \pm 1133$ & $500-5119$ \\
\hline Transduced CD3+ cells $\left(\times 10^{6}\right)$ & $517 \pm 223$ & $150-763$ & $1940 \pm 775^{a}$ & $837-3018$ & $1064 \pm 877$ & $150-3018$ \\
\hline CD3+ cells (\%) & $95.4 \pm 8.6$ & 74.9-99.9 & $95.1 \pm 6.0$ & $83.1-98.7$ & $95.3 \pm 25.5$ & 74.9-99.9 \\
\hline Transduced CD3+ cells (\%) & $52.8 \pm 15.0$ & $30.0-69.3$ & $45.7 \pm 12.0$ & $33.5-63.7$ & $50.1 \pm 21.3$ & $30.0-69.3$ \\
\hline CD4+ cells (\%) & $50.6 \pm 14.8$ & $24.9-72.3$ & $38.1 \pm 17.2$ & $14.1-57.1$ & $45.8 \pm 19.7$ & $14.1-72.3$ \\
\hline CD8+ cells (\%) & $42.4 \pm 16.5$ & $18.3-65.7$ & $53.3 \pm 15.2$ & $35.3-74.1$ & $45.6 \pm 19.6$ & $18.3-74.1$ \\
\hline
\end{tabular}

${ }^{a} \mathrm{p}<0.05$ for comparison of CD19- and GD2-CART cells 

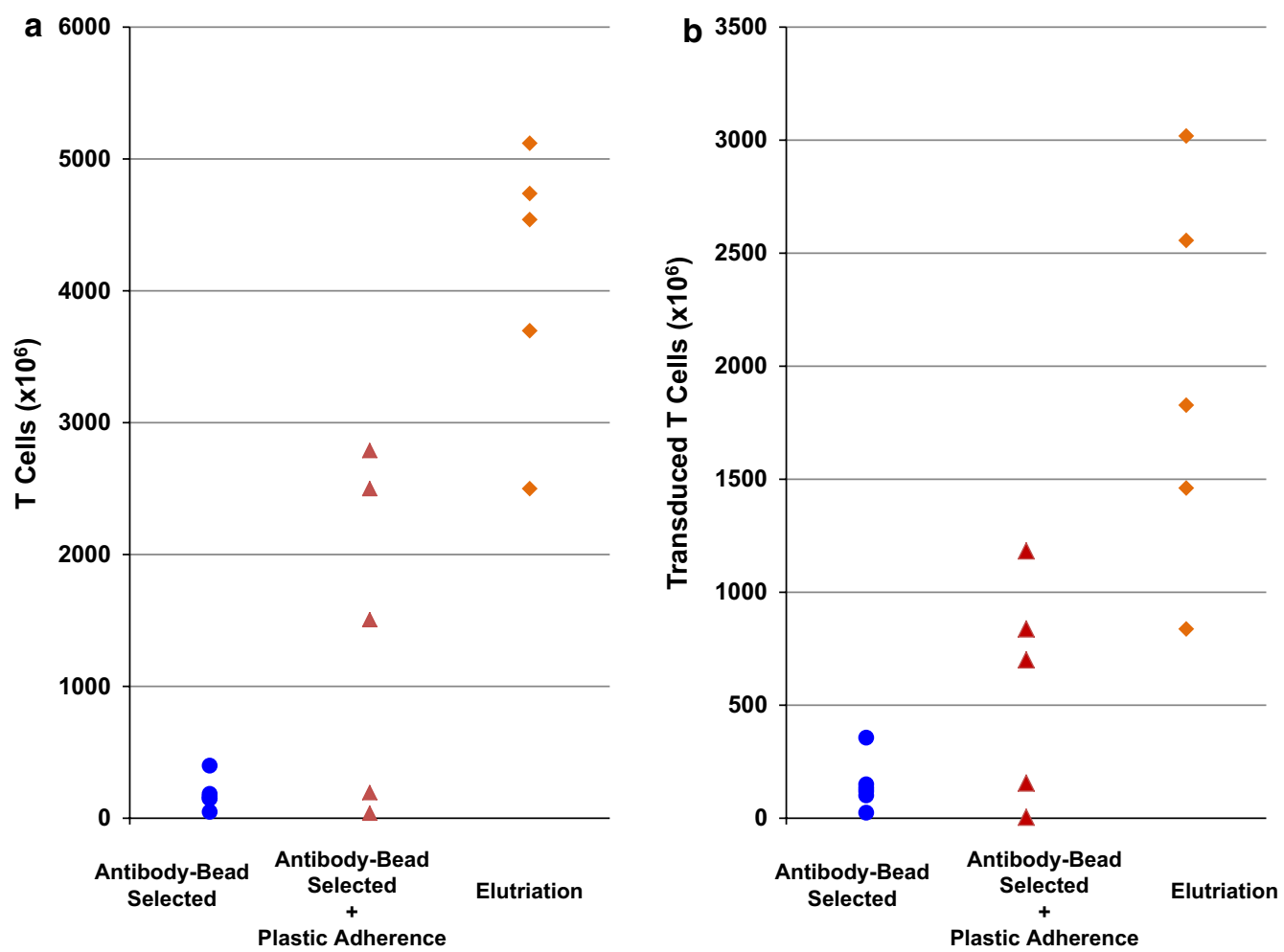

Fig. 1 Quantity of T cells and transduced T cells in GD2-CART cell products. GD2-CART cells were manufactured over 10 or 11 days using autologous PBMC concentrates enriched for lymphocytes using one of 3 methods: anti-CD3/CD28 bead selection ( $n=6$, circles), anti-CD3/CD28 bead selection plus plastic adherence $(n=5$, triangle) and elutriation $(n=5$, diamonds). The quantity of CD3 + cells in the final product is shown in $\mathbf{a}$ and transduced CD3+ cells in $\mathbf{b}$

anti-CD3/CD28 bead plus adherence enriched cells $\left(576 \pm 437 \times 10^{6} ; p=0.015\right)$ (Fig. 1b). For CD19-CAR $\mathrm{T}$ cells, greater quantities of $\mathrm{T}$ cells were produced from elutriated lymphocytes $\left(946 \pm 273 \times 10^{6}\right)$ than from anti-CD3/CD28 bead enriched $\left(305 \pm 280 \times 10^{6}\right.$; $\left.p=8.34 \times 10^{-4}\right)$ and bead plus adherence enriched cells $\left(577 \pm 284 \times 10^{6} ; p=6.04 \times 10^{-3}\right)$ (Fig. 2a), but the quantities of transduced $\mathrm{T}$ cells were no greater from elutriation enriched lymphocytes $\left(517 \pm 223 \times 10^{6}\right)$ than from anti-CD3/CD28 bead enriched $\left(253 \pm 227 \times 10^{6} ; p=0.052\right)$ or beads selection plus adherence enriched cells $\left(410 \pm 183 \times 10^{6}\right.$; $p=0.223$ ) (Fig. 2b).

There was no difference in transduction efficiencies of $\mathrm{T}$ cells among the GD2-CAR $\mathrm{T}$ cells manufactured using PBMC concentrates enriched by elutriation and bead selection plus adherence $(45.7 \pm 12.0$ versus $42.6 \pm 22.5 \% ; p=0.81$ ); both were transduced once. GD2-CAR $\mathrm{T}$ cells manufactured with cells enriched by anti-CD3/CD28 bead selection alone were transduced twice and the transduction efficiency was greater $(75.1 \pm 14.6 \%)$ than those manufactured with cells enriched by elutriation $\left(p=9.70 \times 10^{-3}\right)$ and beads plus adherence $(p=0.0283)$. All CD19-CAR T cell products were transduced twice but the transduction efficiencies were less for CD19-CAR $T$ cells manufactured using elutriation enriched cells than anti-CD3/CD28 bead plus adherence enriched cells $(52.8 \pm 15.0$ versus $72.7 \pm 12.1 \% ; p=1.9 \times 10^{-3}$ ) but not anti-CD3/CD28 bead enriched cells (76.4 $\pm 26.6 \% ; p=0.055)$.

We also compared the CD4 and CD8 composition of CAR T cells manufactured from lymphocytes enriched using the 3 different methods and found no difference in the proportion of CD3+ cells that expressed CD4 and CD8 among CAR $\mathrm{T}$ cells manufactured from PBMCs enriched for lymphocytes or $\mathrm{T}$ cells using the 3 different methods (Table 4).

\section{Discussion}

We investigated manufacturing CAR T cells using autologous $\mathrm{PBMC}$ concentrates enriched for lymphocytes using counter flow elutriation. The number of clinical products analyzed was relatively small, but we found that elutriation was effective at enriching autologous PBMC products for lymphocytes and depleting the product of monocytes and granulocytes. 

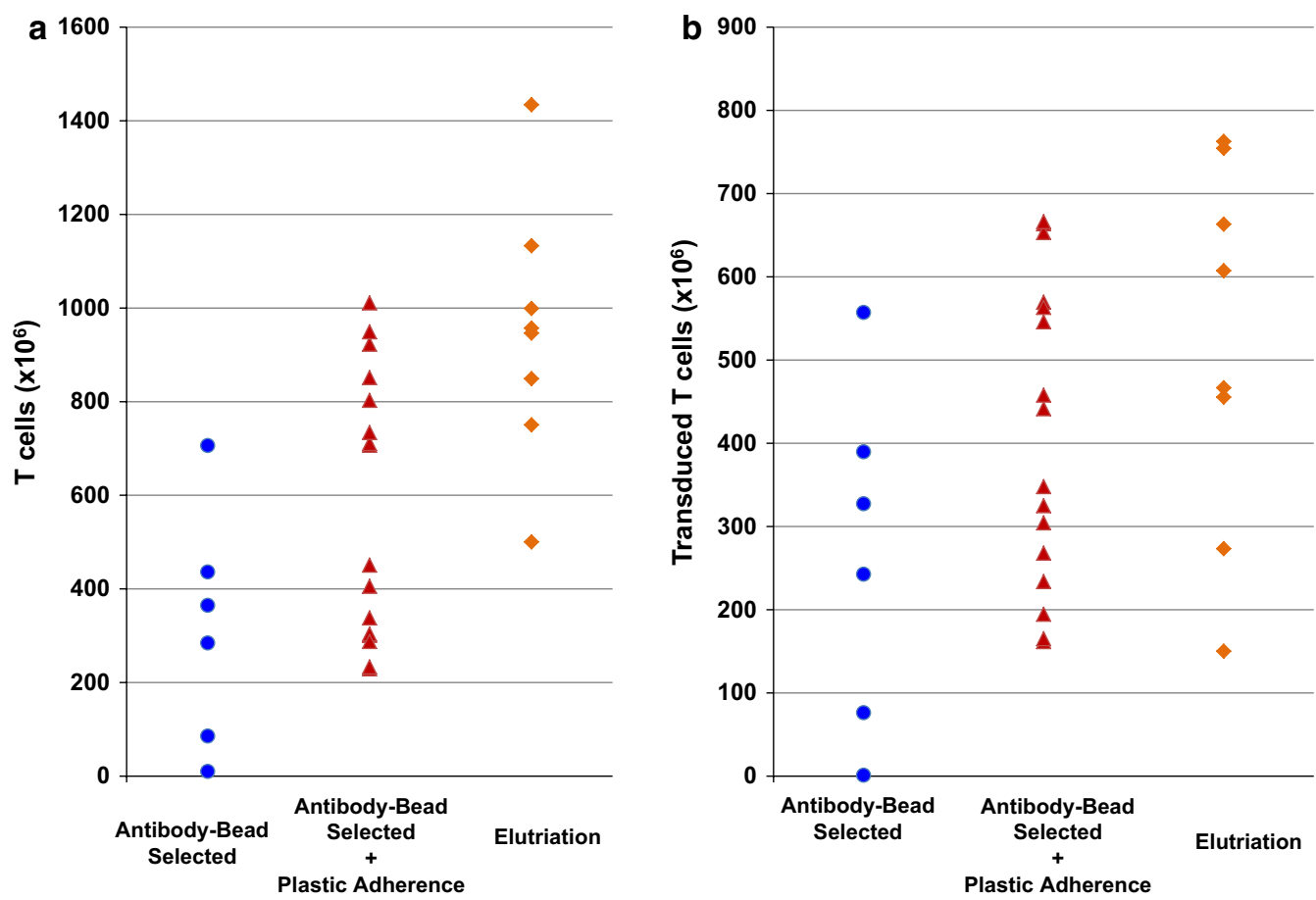

Fig. 2 Quantity of T cells and transduced T cells in CD19-CART cell products. CD19-CART cells were manufactured over 7-9 days using autologous PBMC concentrates enriched for lymphocytes using one of 3 methods: anti-CD3/CD28 bead selection ( $n=6$, circles), anti-CD3/CD28 bead selection plus plastic adherence $(n=16$, triangle) and elutriation $(n=8$, diamonds). The quantity of CD3+ cells in the final product is shown in $\mathbf{a}$ and transduced CD3+ cells in $\mathbf{b}$

Table 4 Comparison of the portion of CD4+ and CD8+ cells in CAR T cells manufactured from PBMC concentrates enriched for lymphocytes using 3 different methods

\begin{tabular}{|c|c|c|c|c|c|c|}
\hline \multirow[t]{3}{*}{ Lymphocyte enrichment method } & \multicolumn{6}{|c|}{ CAR T cell type } \\
\hline & \multicolumn{3}{|c|}{ CD19 } & \multicolumn{3}{|c|}{ GD2 } \\
\hline & $\mathbf{n}$ & CD4 & CD8 & $\mathbf{n}$ & CD4 & CD8 \\
\hline Anti-CD3/CD28 beads & 6 & $54.5 \pm 26.1$ & $35.0 \pm 25.1$ & 6 & $45.8 \pm 12.3$ & $48.4 \pm 14.7$ \\
\hline Anti-CD3/CD28 beads + plastic adherence & 16 & $57.3 \pm 15.7$ & $38.4 \pm 14.8$ & 5 & $48.0 \pm 48.7$ & $40.0 \pm 10.1$ \\
\hline Elutriation & 8 & $50.6 \pm 14.8$ & $42.4 \pm 16.5$ & 5 & $38.1 \pm 17.1$ & $53.2 \pm 15.1$ \\
\hline
\end{tabular}

When compared to methods that we have previous used to enrich PBMC concentrates for T cells or lymphocytes, anti-CD3/CD28 bead selection and bead selection plus plastic adherence, beginning manufacturing with elutriated lymphocytes resulted in greater $\mathrm{T}$ cell yields. Furthermore, the yield of T cells transduced with GD2CAR was greatest when manufacturing was initiated with elutriated lymphocytes, but this was not the case with CD19-CAR T cell products. While the overall $\mathrm{T}$ cell yields for CD19-CAR $T$ cell products was greatest when manufacturing was initiated with elutriated lymphocytes, the CD19-CAR T cell transduction efficiency was less for the cells produced from elutriated lymphocytes and there was no significant increase in the yield of transduced CD19 CAR T cells.

Among the 13 CD19- and GD2-CAR T cells products manufactured using elutriated lymphocytes, all products contained enough transduced $\mathrm{T}$ cells to meet protocol dose requirements. We have previously found that CAR $\mathrm{T}$ cells manufactured using $\mathrm{T}$ cells selected with antiCD3/CD28 beads failed to contain sufficient quantities of transduced $\mathrm{CD} 3+$ cells to meet protocol dose criteria in 4 of 28 CD19-CAR T cell patients and none of 6 GD2CAR $T$ cell patients [11]. A change in the manufacturing process to include a monocyte depletion step using plastic adherence reduced the number of products that 
did not meet dose criteria to 1 of 20 patients; none of 15 CD19-CAR T cell products and to 1 of 5 GD2-CAR T cell products [11].

The finding that beginning manufacturing with elutriated lymphocytes improved GD2-CAR T cell expansion more than CD19-CAR T cells is likely due to the presence of greater quantities of myeloid cells in autologous PBMC concentrates used to manufacture GD2-CAR T cells. Most patients treated with GD2-CAR T cells had osteosacrcoma who are known to have circulating myeloid-derived suppressor cells (MDSCs) [14]. The patients treated in this study with CD19-CAR T cells most often had ALL and patients with hematologic malignancies are less likely to have circulating MDSCs $[15,16]$.

One limitation of the use of elutriation to isolate lymphocytes for CAR $\mathrm{T}$ production is that the elutriated lymphocyte fraction not only contains $\mathrm{T}$ cells, but it also contains B cells and NK cells and RBCs. A portion of acute lymphocyte leukemia blast cells are also found in the lymphocyte fraction. While we continue to initiate GD2-CAR T cell manufacturing with elutriated lymphocytes, we are investigating other, more specific methods of $\mathrm{T}$ cell purification for manufacturing CAR $\mathrm{T}$ cells for patients with ALL in order to improve T cell expansion and to exclude leukemic cells from being transduced.

\section{Conclusions}

We found that counter flow elutriation of PBMC concentrates collected from children and young adults with ALL and sarcoma produced lymphocyte fractions with reduced quantities of neutrophils and monocytes. CAR $\mathrm{T}$ cells can be consistently produced and expanded from elutriated lymphocytes. These results provide further evidence of the importance of beginning CAR $T$ cell manufacturing with lymphocytes that contain few contaminating myeloid cells.

\footnotetext{
Abbreviations

ALL: acute lymphocytic leukemia; BCMA: B cell maturation antigen; CAR: chimeric antigen receptors; MDSC: myeloid-derived suppressor cells; $\mathrm{NCl}$ : National Cancer Institute; PBMC: peripheral blood mononuclear cells; RBCs: red blood cells.
}

\section{Authors' contributions}

DFS, MS, HK, DWL and CM designed the study. DFS, JR and SH summarized the data. DWL, NNS, RNK, TJF and CM designed and lead the clinical trials. DFS drafted the manuscript and all authors contributed to the revision of the manuscript. All authors read and approved the final manuscript.

\footnotetext{
Author details

${ }^{1}$ Cell Processing Section, Department of Transfusion Medicine, NIH Clinical Center, NIH, 10 Center Drive-MSC-1184, Building 10, Room 3C720, Bethesda, MD 20892-1184, USA. ${ }^{2}$ Pediatric Oncology Branch, Center for Cancer Research, National Cancer Center, NIH, Bethesda, USA. ${ }^{3}$ Division of Pediatric Hematology/Oncology, Department of Pediatrics, University of Virginia, Charlottesville, USA. ${ }^{4}$ Parker Institute for Cancer Immunotherapy, Stanford University, Stanford, USA.
}

\section{Acknowledgements}

The authors thank the staff of the Cell Processing Section of the Department of Transfusion Medicine, Clinical Center, NIH for preparing the CART cell products.

\section{Competing interests}

The authors declare that they have no competing interests.

\section{Availability of data}

The datasets analysed during the current study are available from the corresponding author on reasonable request.

\section{Ethics approval and consent to participate}

These studies were approved by the IRB of the NCI, NIH Bethesda, Maryland, USA. Informed consent was obtained from all participants.

\section{Funding}

This research was supported by the Intramural Research Program of the NIH, Clinical Center and National Cancer Institute.

Received: 13 February 2017 Accepted: 8 March 2017

Published online: 16 March 2017

\section{References}

1. Lee DW, Kochenderfer JN, Stetler-Stevenson M, Cui YK, Delbrook C, Feldman SA, Fry TJ, Orentas R, Sabatino M, Shah NN, et al. T cells expressing CD19 chimeric antigen receptors for acute lymphoblastic leukaemia in children and young adults: a phase 1 dose-escalation trial. Lancet. 2015;385(9967):517-28

2. Kochenderfer JN, Yu Z, Frasheri D, Restifo NP, Rosenberg SA. Adoptive transfer of syngeneic $T$ cells transduced with a chimeric antigen receptor that recognizes murine CD19 can eradicate lymphoma and normal B cells. Blood. 2010;116(19):3875-86.

3. Brudno JN, Somerville RP, Shi V, Rose JJ, Halverson DC, Fowler DH, GeaBanacloche JC, Pavletic SZ, Hickstein DD, Lu TL, et al. Allogeneic T cells that express an anti-CD19 chimeric antigen receptor induce remissions of B-cell malignancies that progress after allogeneic hematopoietic stem-cell transplantation without causing graft-versus-host disease. J Clin Oncol. 2016;34(10):1112-21.

4. Porter DL, Levine BL, Kalos M, Bagg A, June CH. Chimeric antigen receptor-modified T cells in chronic lymphoid leukemia. N Engl J Med. 2011;365(8):725-33

5. Grupp SA, Kalos M, Barrett D, Aplenc R, Porter DL, Rheingold SR, Teachey DT, Chew A, Hauck B, Wright JF, et al. Chimeric antigen receptor-modified T cells for acute lymphoid leukemia. N Engl J Med. 2013;368(16):1509-18.

6. Maude SL, Frey N, Shaw PA, Aplenc R, Barrett DM, Bunin NJ, Chew A, Gonzalez VE, Zheng Z, Lacey SF, et al. Chimeric antigen receptor T cells for sustained remissions in leukemia. N Engl J Med. 2014;371(16):1507-17.

7. Garfall AL, Maus MV, Hwang WT, Lacey SF, Mahnke YD, Melenhorst $\mathrm{JJ}$, Zheng Z, Vogl DT, Cohen AD, Weiss BM, et al. Chimeric antigen receptor $T$ cells against CD19 for multiple myeloma. N Engl J Med. 2015;373(11):1040-7.

8. Porter DL, Hwang WT, Frey NV, Lacey SF, Shaw PA, Loren AW, Bagg A, Marcucci KT, Shen A, Gonzalez V, et al. Chimeric antigen receptor T cells persist and induce sustained remissions in relapsed refractory chronic lymphocytic leukemia. Sci Transl Med. 2015;7(303):303ra139.

9. Ali SA, Shi V, Maric I, Wang M, Stroncek DF, Rose JJ, Brudno JN, StetlerStevenson M, Feldman SA, Hansen BG, et al. T cells expressing an anti-Bcell maturation antigen chimeric antigen receptor cause remissions of multiple myeloma. Blood. 2016;128(13):1688-700.

10. Allen ES, Stroncek DF, Ren J, Eder AF, West KA, Fry TJ, Lee DW, Mackall CL, Conry-Cantilena C. Autologous lymphapheresis for the production of chimeric antigen receptor T cells. Transfusion. 2017. doi:10.1111/trf.14003.

11. Stroncek DF, Ren J, Lee DW, Tran M, Frodigh SE, Sabatino M, Khuu H, Merchant MS, Mackall CL. Myeloid cells in peripheral blood mononuclear cell concentrates inhibit the expansion of chimeric antigen receptor $\mathrm{T}$ cells. Cytotherapy. 2016;18(7):893-901. 
12. Stroncek DF, Fellowes V, Pham C, Khuu H, Fowler DH, Wood LV, Sabatino M. Counter-flow elutriation of clinical peripheral blood mononuclear cell concentrates for the production of dendritic and T cell therapies. J Transl Med. 2014;12:241.

13. Tumaini B, Lee DW, Lin T, Castiello L, Stroncek DF, Mackall C, Wayne A, Sabatino M. Simplified process for the production of anti-CD19-CARengineered T cells. Cytotherapy. 2013;15(11):1406-15.

14. Zhang H, Maric I, DiPrima MJ, Khan J, Orentas RJ, Kaplan RN, Mackall CL. Fibrocytes represent a novel MDSC subset circulating in patients with metastatic cancer. Blood. 2013;122(7):1105-13.
15. De Veirman K, Van Valckenborgh E, Lahmar Q, Geeraerts X, De Bruyne E, Menu E, Van Riet I, Vanderkerken K, Van Ginderachter JA. Myeloid-derived suppressor cells as therapeutic target in hematological malignancies. Front Oncol. 2014:4:349.

16. Yazdani Y, Mohammadnia-Afrouzi M, Yousefi M, Anvari E, Ghalamfarsa G, Hasannia H, Sadreddini S, Jadidi-Niaragh F. Myeloid-derived suppressor cells in B cell malignancies. Tumour Biol. 2015;36(10):7339-53.

\section{Submit your next manuscript to BioMed Central and we will help you at every step:}

- We accept pre-submission inquiries

- Our selector tool helps you to find the most relevant journal

- We provide round the clock customer support

- Convenient online submission

- Thorough peer review

- Inclusion in PubMed and all major indexing services

- Maximum visibility for your research

Submit your manuscript at

www.biomedcentral com/submit 